\title{
PERANCANGAN BUKU SENJATA KURAMBIK KHAS MINANGKABAU SUMATERA BARAT
}

\author{
Ferry Fernando \\ Mahasiswa Program Magister Penciptaan dan Pengkajian Seni, \\ Institut Seni Indonesia Yogyakarta. \\ Dosen Jurusan Desain Komunikasi Visual, \\ Fakultas Seni Rupa \& Desain (FSRD) ISI Padang Panjang, \\ Email: ferrydamara@gmail.com
}

\begin{abstract}
The design of typical Minangkabau book kurambik weapon, aim to be expected to be a complete visual documents about weapons kurambik / kerambit Minangkabau and can be used as a reference in teaching and research. It also aims to maintain continuity kurambik weapons and maintained on an ongoing basis as a product of the culture of Indonesia. This book is one way to be able to keep kurambik remain in the State of Indonesia.

This book is based on the use of photo etnofotografi which is more likely than artistic. Because etnofotografi is the study of a culture of a society with the help of photos in it. Picture elements should be able to describe the social structure, dominance, social class and other cultural symbols. Etnofotografi rooted in ethnography.

Minangkabau kurambik book "Indak Lakang Dek Paneh, Indak Lapuak Dek Hujan" comes as a gap filler kurambik media about guns that had not been there. The book is expected to be a reference and teaching materials also stimulated interest in research to examine kurambik weapons.
\end{abstract}

Keywords: Design books, Etnofotografi, Weapons kurambik

\section{Pendahuluan}

Desain buku adalah seni menggabungkan isi, gaya, bentuk, desain, dan urutan berbagai komponen sebuah buku ke dalam keutuhan yang koheren. Menurut Jan Tschichold, meski banyak dilupakan dewasa ini, metode dan urutan perancangan buku telah dikembangkan selama berabad-abad. Untuk menghasilkan bukubuku yang sempurna, aturan-aturan tersebut harus dihidupkan kembali dan diterapkan (Handel, 1998:7). Richard Hendel menggambarkan desain buku sebagai suatu hal yang misterius (rahasia) dan membutuhkan suatu konteks untuk memahami maknanya (1998:1).

Seorang desainer komunikasi visual yang professional harus memiliki pengetahuan dan kemampuan yang luas tentang komunikasi visual. Selain visualisasi dan bakat yang baik dalam berkomunikasi secara visual, ia juga harus mempunyai kemampuan untuk menganalisa suatu masalah, mencari solusi masalah tersebut dan mempresentasikannya secara visual ( Cotton, 1990:42). Desain adalah suatu disiplin ilmu yang tidak hanya mencakup eksplorasi visual, tatpi terkait dan mencakup pula dengan aspek-aspek seperti kultural-sosial, filosofis, teknis dan bisnis. Desain merupakan suatu studi yang bersifat disiplin silang karena kreativitas dan evaluasi desain pada umumnya berdasarkan model dan pelajaran disiplin lainnya (Safanayong, 2006:2).

Komunikasi adalah suatu proses, bukan sesuatu yang bersifat statis. Komunikasi memerlukan tempat, dinamis, menghasilkan perubahan dalam usaha mencapai hasil, melibatkan interaksi bersama, serta melibatkan suatu kelompok. Komunikasi dikatakan efektif apabila terdapat aliran informasi dua arah antara 
komunikator dan komunikan dan informasi tersebut sama-sama direspon sesuai dengan harapan kedua pelaku komunikasi tersebut.

\section{Pembahasan}

Etnografi adalah suatu kebudayaan yang mempelajari kebudayaan lain. Etnografi merupakan suatu bangunan pengetahuan yang meliputi teknik penelitian, teori etnografis dan berbagai macam deskripsi kebudayaan. Etnografi bermakna untuk membangun suatu pengertian yang sistematik mengenai semua kebudayaan manusia dari perspektif orang yang telah mempelajari kebudayaan itu (Spradley, 2006:13)

Sebagai permulaan, dalam proses awal penciptaan ini etnografi lebih sekedar cara pengumpulan data di lapangan, namun juga merupakan seperangkat metode, seperti wawancara mendalam, observasi atau survey yang harus sesuai dan merefleksikan kerangka kerja teoritis dan filosofis yang lebih luas, yakni metodologi. Menurut J.D. Brewer (200:27), etnografi merupakan studi lapangan mengenai manusia secara alami. Melalui metode pengumpulan data ini dapat menangkap makna sosial dan aktivitas keseharian masyarakat yang melibatkan penelitian secara langsung dalam aktivitas tersebut.

Etnografi merupakan pekerjaan mendeskripsikan suatu kebudayaan. Tujuan utama adalah memahami suatu pandangan hidup dari sudut pandang penduduk asli. Menurut Malinowski, tujuan etnografi adalah memahami sudut pandang penduduk asli, hubungan dengan kehidupan, untuk mendapatkan pandangannya mengenai dunianya (1922:25).

Fotografi berasal dari istilah Yunani: phos yang berarti cahaya dan graphein yang berarti menggambar. Istilah tersebut pertama kali oleh Sir John Herschel pada tahun 1839. Jadi kata fotografi adalah menggambar dengan cahaya.

Penemuan teknik fotografi dalam satu hal telah mengurangi daerah gerak seni lukis, karena fotografi yang dengan cepat dan tepat mampu merekam objek itu menggantikan sebagian fungsi seni lukis yaitu fungsi dokumentasi dan fungsi penyajian presentasi realistik bagi objek-objeknya (Soedarso, 2000:8). Fotografi bisa dikatakan sebagai kegiatan penyampaian pesan secara visual dari pengalaman yang dimiliki seniman/fotografer kepada orang lain dengan tujuan orang lain mengikuti jalan pikirannya. Supaya tercapai proses penyampaian pesan ini maka harus melalui beberapa persyaratan komunikasi yang baik, yaitu konsep AIDA (Attention-Interest-Desire-Action) atau perhatian - ketertarikan - Keinginan - Tindakan (Susanto, 1984:11).

Fotografi menampilkan kenyataan (realita) dan tidak ada unsur abstrak (dalam seni fotografi) (Giwanda, 2002:6). Suatu kenyataan bahwa pembuatan seni fotografi dengan kamera berarti membatasi subjek dengan batas format pada jendela pengamat. Hal ini menjadikan seni fotografi lebih jujur dari pada seni lainnya karena merekam seperti memfotocopy subjek yang ada di depannya. Subjek foto mencakup banyak hal yang tidak terbatas, mulai dari pemotretan manusia, alam semesta, arsitektur, sampai dengan mikroorganisme. Dalam buku ini, fotografi digunakan sebagai media identifikasi bagi khalayak sasaran. Sigmund Freud mengungkapkan bahwa identifikasi merupakan cara mereduksi tegangan dengan meniru (mengimitasi) atau mengidentifikasikan diri dengan orang yang dianggap lebih berhasil memuaskan hasratnya disbanding dirinya. (Alwisol, 2005:31). 
Menurut Karnadi (1998: 3), etnofotografi merupakan aplikasi dari fotografi dan etnografi. Dasar utama penetapan istilah etnofotografi ialah fotografi (sebagai pekerjaan membuat foto) untuk menyelidiki peran kebudayaan dalam pembentukan pribadi manusia.Hal tersebut lazim yang dipakai antropolog untuk menyelidiki peran kebudayaan manusia berdasarkan foto yang ada. Jadi pengertian etnofotografi adalah untuk menelaah keadaan budaya sebuah masyarakat dengan media komunikasi visual fotografi. Menurut Yuyung Abdi (2012: 38), etnofotografi adalah penggunaan fotografi sebagai metode analisis kebudayaan, tata hidup, pengaturan, dan komunikasi dalam kehidupan sehari-hari. Dalam hal ini, yang lebih dipentingkan adalah substansi foto ketimbang sisi artistiknya. Elemen-elemen foto harus mampu menggambarkan struktur sosial, dominasi, kelas sosial dan simbol-simbol budaya lainnya. Etnofotografi berakar dari etnografi. Namun, etnofotografi lebih menitikberatkan pada segi visual dengan menggunakan fotografi sebagai mediumnya.

Sementara itu Erwin Polofsky menyatakan bahwa Etnofotografi merupakan salah satu dari kajian Budaya Visual yang khusus mempelajari foto sebagai bukti sejarah, memori sosial ataupun realita yang tersurat melalui foto. Etnofotografi bukanlah ilmu untuk mengambil foto, melainkan analisis foto, bagaimana tujuan dan maksud dari foto yang dihasilkan. Termasuk aplikasi foto terhadap pihak yang lain (Persepsi dan apreasiasi) "WHAT YOU SEE IS WHAT YOU $G E T^{\prime \prime}$. Jadi etnofotografi dalam perancangan ini yaitu cara untuk mengkomunikasikan kebudayaan melalui fotografi. Bukan hanya sekedar fotografi, tetapi didukung dengan pendekatan etnografi mengenai senjata kurambik sehingga nantinya para pembaca bisa mengetahui makna yang terkandung dalamnya.

Negeri ini memang begitu kaya rupawan. Berbagai macam budaya mewarnai kehidupan para penghuninya. Dari sekian banyak produk-produk budaya bangsa ini salah satunya yaitu senjata. Senjata merupakan simbol dari suatu peradaban bangsa. Banyak sekali macam-macam senjata tradisional yang ada di Nusantara ini khususnya senjata tajam. Senjata tajam tradisional khas daerah-daerah di Indonesia tidak hanya memiliki nilai fungsional, namun juga nilai artistik yang membawa kebanggaan tersendiri bagi pemegangnya. Akan tetapi, keberadaan senjata tradisional khas daerah-daerah itu banyak yang belum dikenal dalam skala nasional, apalagi internasional. Padahal, berbagai senjata tajam tradisional, khas daerah-daerah di Indonesia berpotensi untuk dikembangkan dan dikomersialisasikan. Apalagi upaya pengembangan dan komersialisasi itu juga dinilai penting, karena terbukti mampu menyerap tenaga kerja dan menjadi sumber ekonomi masyarakat di daerah-daerah.

Namun, agar senjata tradisional itu bisa memiliki kualitas yang baik sehingga bisa diakui dunia, diperlukan kesungguhan, dedikasi, dan nilai artistik tinggi dalam proses pembuatannya. Dalam hal ini, senjata tradisional yang eksklusif nan indah dan cantik, namun tetap berfungsi dan dapat difungsikan, bukanlah sesuatu yang mustahil.

Senjata tajam tradisional sangat memungkinkan untuk mendunia, jika melihat dukungan media massa dan pemerintah dalam kegiatan promosi hingga ke luar negeri. Kujang, rencong, Mandau, keris, badik, dan lainnya akan mendunia jika didukung juga oleh cerita dan 
promosi yang baik. Saat ini keris sudah dipopulerkan dengan kekuatan metafisiknya. Begitu juga dengan kujang dan rencong. Model senjata tajam khas Indonesia sangat beragam, namun banyak yang belum tergali secara optimal. Sisi positifnya, ini memungkinkan untuk upaya pengembangan, khususnya dengan desain produk yang baru dan layak untuk ditawarkan ke pasar.

Selain itu, sifat senjata tajam tradisional yang berkategori benda seni fungsional juga masih diminati berbagai kalangan. Sebut saja kalangan rumah tangga, pemburu, Meliter, kolektor, pemerhati budaya, cinderamata, dan sebagainya. Adapun jenis-jenis senjata tajam tradisional khas nusantara yaitu :

$\begin{array}{ll}\text { - Rencong } & \text { - Keris } \\ \text { - Kujang } & \text { - Golok } \\ \text { - Clurit } & \text { - Badik } \\ \text { - Bambu runcing } & \text { - Tombak } \\ \text { - Karih } & \text { - Badik tumbuk lada } \\ \text { - Klewang } & \text { - Kuku macan } \\ \text { - Parang sikim } & \text { - Parang lading } \\ \text { - Klewang maremu } & \text { - Rawit } \\ \text { - Pedang batak } & \text { - Badik batak } \\ \text { - Sumpit } & \text { - Sundu } \\ \text { - Belati papua } & \text { - Piso surit } \\ \text { - Piso gaja dompak } & \text { - Panah } \\ \text { - Punta } & \text { - Beliung gigi gledek } \\ \text { - Cunrik } & \text { - Kerambit } \\ \text { - Siwah } & \text { - Siwar } \\ \text { - Mandau } & \text { - Parang } \\ \text { - Jenawi } & \end{array}$

Dari beberapa senjata tradisional nusantara ini salah satu yang masih asing ditelinga masyarakat yaitu kerambit/kurambik. Menurut Tambo Minangkabau, Kurambik merupakan jenis senjata asli Minangkabau Sumatera Barat, termasuk senjata khas andalan yang sangat berbahaya. Dalam aksen Minangkabau disebut "kurambik". Istilah kurambik berasal dari kata ukuran dan ambiak. Ukuran mengandung makna berkesesuaian sedangkan ambiak berarti mengambil atau meraih. Pada masa dahulu, permainan senjata Kurambik di Minangkabau hanya diwarisi oleh para Datuk atau kalangan Raja, tidak sembarang orang menguasai permainan yang dianggap rahasia dan hanya untuk kalangan tertentu saja.

Kurambik dari Minangkabau atau Dataran Tinggi Sumatera memiliki berbagai sudut lengkung dari hampir 90 derajat sampai $\pm 25-30$ derajat, ada yang tajamnya dua sisi maupun satu sisi. Bentuk kurambik ini diadaptasi dari bentuk kuku harimau atau taring harimau. Dalam klasifikasi senjata genggam paling berbahaya, Kurambik sebagai senjata mematikan menempati urutan kedua setelah pistol. Sabetan senjata Kurambik bila mengenai tubuh lawan, dari luar memang tampak seperti luka sayatan kecil, namun pada bagian dalam tubuh bisa menimbulkan akibat yang sangat fatal karena urat-urat putus. Apabila mengenai perut, maka usus terpotong atau tercabik-cabik didalam. Kelebihan dari Kurambik adalah bentuknyah kecil dan mudah disembunyikan. Sulit untuk di disarmed atau dilucuti dalam pertarungan. Jarak bisa berubah tanpa ada gerakan footwork atau merubah langkah. Mampu untuk dua serangan dalam satu gerakan tangan. Lebih membuat robekan besar untuk gerakan-gerakan tarikan. Serangan cepat dengan pegangan standart secara pukulan $j a b$.

Kurambik dalam kehidupan orang minangkabau tidak lepas dari filosofi orang minang itu sendiri yaitu "Alam Takambang Jadi Guru'"(Alam terkembang jadi guru). Semua ajaran dan pandangan hidup mereka yang dinukilkan dalam pepatah, petitih, pituah, mamangan, serta lain-lainnya mengambil ungkapan dari bentuk, 
sifat, dan kehidupan alam. Alam dan segenap unsurnya mereka lihat senantiasa terdiri dari empat atau dapat dibagi dalam empat, yang mereka sebut nan ampek (yang empat). Seperti halnya : ada matahari, ada bulan, ada bumi, ada bintang, ada siang, ada malam, ada pagi, ada petang, ada timur, ada barat, ada utara, ada selatan; ada api, ada air, ada tanah, ada angin. Semua unsur alam yang berbeda kadar dan perannya itu saling berhubungan tetapi tidak saling mengikat, saling berbenturan tapi tidak saling melenyapkan, dan saling mengelompok tapi tidak saling meleburkan. Unsur - unsur itu masing - masing hidup dengan eksistensinya dalam suatu harmoni, tetapi dinamis sesuai dengan dialektika alam yang mereka namakan bakarano bakajadian (bersebab dan berakibat).

Dalam pembuatan sejata di
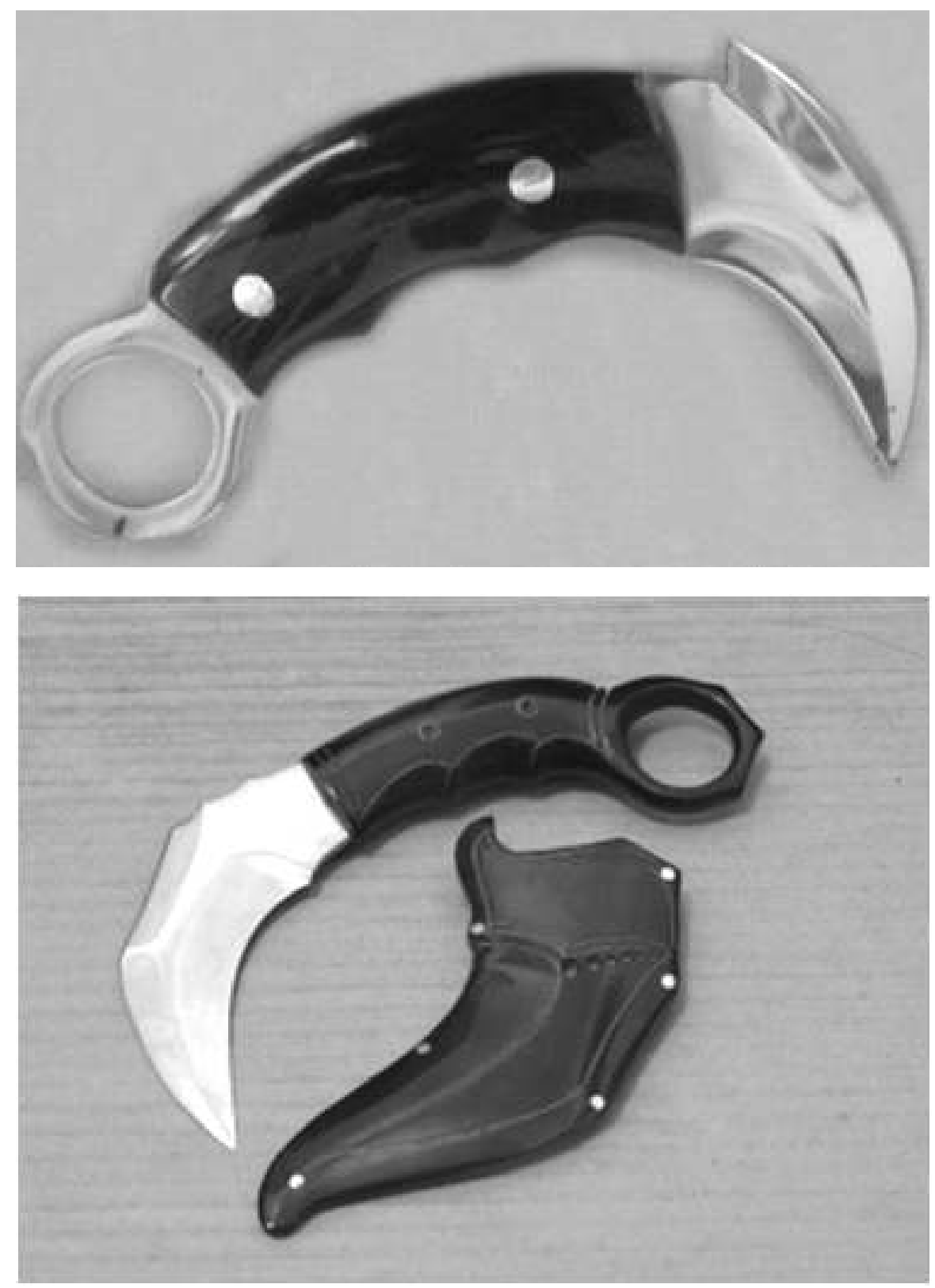

Gambar 1. Kurambik

(Sumber: Dokumentasi Ferry Fernando, 2013 
Minangkabau sangat tergantung dari lingkungan sekitarnya. Senjata banyak dipergunakan untuk kepentingan rakyat seperti menyabit disawah dan ada pula sebagai simbol dari kekuatan penguasa suatu daerah. Seorang datuk atau penghulu biasanya memakai karih/keris, seorang hulubalang atau penjaga keamanan suatu daerah biasanya memakai senjata golok atau ciliang manurun. Sangat jarang sekali senjata itu dikeluarkan dari sarangnya untuk dijadikan sebagai alat membunuh seseorang. Mereka lebih mempergunakan musyawarah atau mufakat untuk menyelesaikan pertikaian yang terjadi antara masyarakat maupun anak kemenakan.

\section{Sejarah Kurambik}

Kurambik merupakan senjata beladiri khas kebudayaan Minangkabau yang diwariskan oleh nenek moyang sejak berada di bumi Minangkabau. Bila dikaji dengan seksama isi Tambo Alam Minangkabau yang penuh berisikan kiasan, berupa pepatah, petitih ataupun mamang adat senjata kurambik ini diciptakan oleh salah seorang penasehat Sultan Sri Maharaja Diraja yang bernama "Datuak Suri Diraja" yang dipanggil dengan Ninik Datuak Suri Diraja oleh anak-cucu sekarang.

Sultan Sri Maharaja Diraja, seorang raja di Kerajaan Pahariyangan (dialek : Pariangan), sebuah negeri yang pertama dibangun di kaki gunung merapi bahagian tenggara pada abad XII (tahun 1119M). Dia menikah dengan adik dari Ninik Datuk Suri Diraja yang bernama Indah Julian. Sedangkan Ninik Datuak Suri Diraja, seorang tua yang banyak dan dalam ilmunya di berbagai bidang kehidupan social. Beliau dikatakan juga sebagai seorang ahli filsafat dan negarawan kerjaan masa itu, serta pertama kalinya membangun dasar-dasar adat minangkabau yang kemudian disempurnakan oleh Datuak Nan Baduo, dikenal dengan Datuak Ketumanggungan dan Datuak Perpatih Nan Sabatang.

Ninik Datuak Suri Diraja itulah yang menciptakan bermacam-macam kesenian dan alatalatnya, seperti pencak,tari-tarian yang diangkatkan dari gerak-gerak silat serta membuat talempong, gong, gendang, serunai, harbah, kecapi dan lain-lain. (I.Dt.Sangguno Dirajo, 1919:18). Ninik Datuk Suri Diraja sebagai salah seorang cendikiawan yang dikatakan "lubuk akal, lautan budi", tempat orang berguru dan bertanya dimasa itu bahkan juga guru dari Sultan Sri Maharaja Diraja. (I.Dt.Sangguno Dirajo, 1919:22). Beliau itu jugalah yang menciptakan bermacam-macam cara berpakaian, seperti bermanik pada leher dan gelang pada kaki dan tangan serta berhias, bergombak satu dan bergombak empat dan sebagainya.

Pengawal - pengawal Sultan Sri Maharaja Diraja yang bernama Kucieng Siam, Harimau Campo, Kambieng Hutan dan Anjieng Mualim menerima warisan ilmu silat sebahagian bersarnya dari Ninik Datuk Suri Dirajo meskipun kepandaian silat pusaka yang mereka miliki dari negeri asal masing-masing sudah ada juga. Mereka merupakan keturunan dari pengawal - pengawal nenek moyang yang mula-mula sekali menjejakkan kaki di kaki gunung merapi.Nenek moyang pertama itu bernama "Dapunta Hyang". (MID.Jamal, 1984:35). Kucieng Siam, seorang pengawal yang berasal dari kawasan Kucin-cina (Siam), Hariamau Campo, seorang pengawal yang gagah perkasa, terampil dari kawasan Campa, Kambieng Hutan, seorang pengawal yang berasal dari Kamboja, dan Anjieng Mualim, seorang pengawal yang datang dari Persia/Gujarat.

Sehubungan dengan itu, kedudukan atau jabatan pengawalan sudah ada sejak nenek 

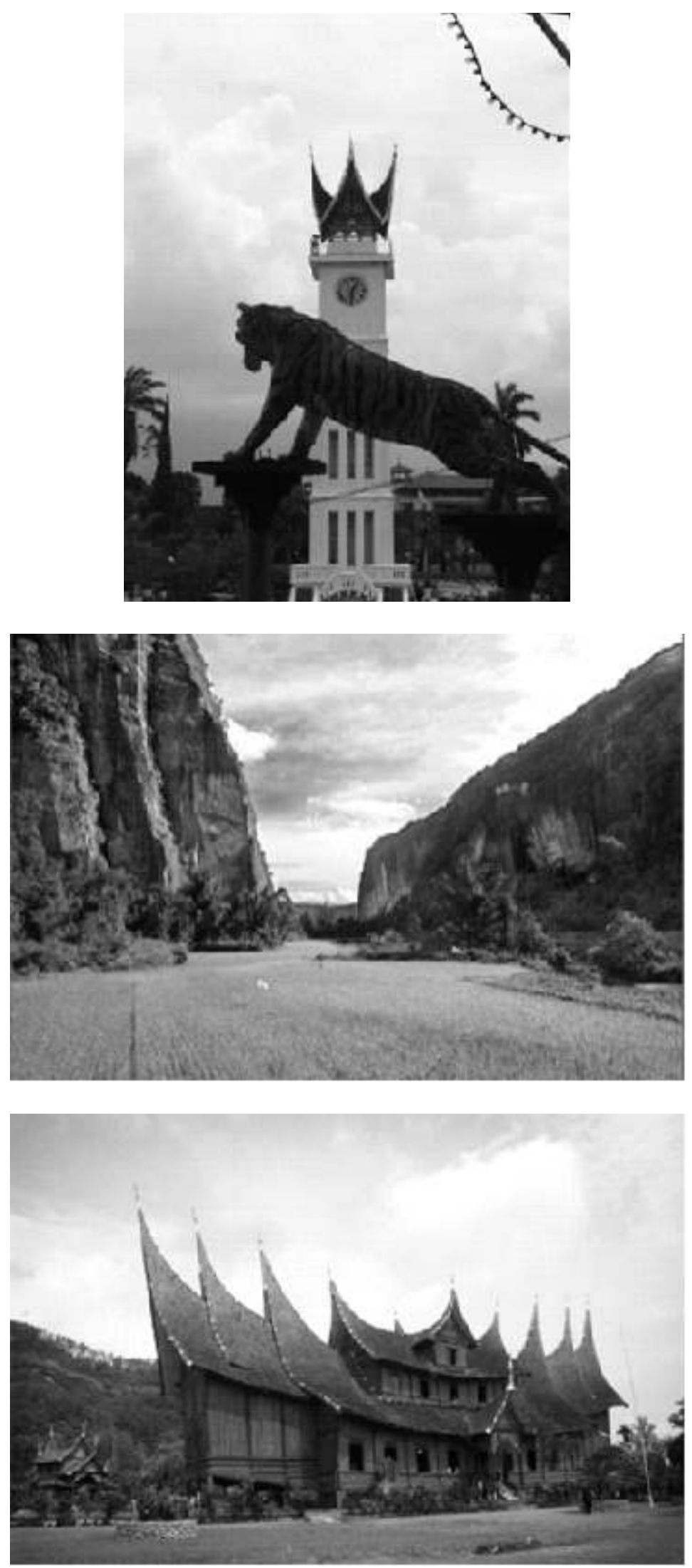

Gambar 2. Luhak Nan Tigo

(Luhak Agam, Luhak Limapuluh, Luhak Tanah Datar) (Sumber: Dokumentasi Ferry Fernando, 2013) 
moyang suku Minangkabau bermukim di daerah sekitar gunung merapi di zaman purba sekurangkurangnya dalam abad I setelah timbulnya kerjaan Melayu di Sumatera Barat. Pada perkembangannya Negeri Paringan terus melakukan perluasan daerah.Karena semakin padatnya penduduk yang ada di Pariangan. Penyebaran penduduk dari Pariangan, dimulai menuju arah ke Timur gunung merapi, yang disebut "Luhak Tanah Datar" (luhak = sumur), lalu dilanjutkan kearah barat gunung merapi, dinamakan "Luhak Agam" (agam = sejenis tumbuhan), dan kemudian kearah Utara gunung merapi, dikenal dengan nama Luhak Limapuluh (Payakumbuh) (kumbuh $=$ sejenis tumbuhan pembuat tikar dan karung). Oleh karena itu sering disebut juga dengan Luhak Nan Tigo yang dibentuk pada tahun (1186M)

Di masa itu terkenal empat angkatan/barisan pertahanan dan keamanan dibawah pimpinan Kucieng Siam, Harimau Campo, Kambieng Hutan dan Anjieng Mualim. Keempatnya merupakan murid-murid Ninik Datuak Suri Dirajo.Dalam perluasan daerah itu rombongan penduduk dipimpin oleh 4 pengawal kerajaan ini. Masing-masing mereka diajarkan ilmu silat oleh Ninik Datuk Suri Dirajo. Salah satu muridnya yaitu Harimau Campo diajarkan silat khusus yaitu silat harimau yang mana lebih mengandalkan kekuatan tangan, terlihat kasar dan gerakan-gerakannya keras, sehingga dikatakan sebagai "pembunuh berdarah panas" karena sifatnya yang menerkam melumpuhkan lawan. Adapun pembagian rombongan penduduk itu yaitu untuk rombongan Ke luhak Tanah Datar, pimpinan rombongan adalah Kucieng Siam.Untuk rombongan ke luhak Agam, pimpinan rombongan adalah Harimau Campo. Untuk rombongan ke luhak Limapuluh-Payakumbuh, pimpinan rombongan adalah Kambieng Hutan. Untuk rombongan ke Tanah Rantau dan pesisir, pimpinan rombongan adalah Anjieng Mualim.

Dalam pergerakan perpindahan penduduk fungsi dan tugas yang dipikul masingmasing rombongan itu diperjelas, sebagai berikut: Barisan pengawal kerajaan, yang disebut Anjieng Mualim berfungsi sebagai watch-dog atau penjaga keamanan. Barisan perusak, yang disebut Kambieng Hutan, berfungsi sebagai destroyer atau zeni. Barisan pemburu, yang disebut Harimau

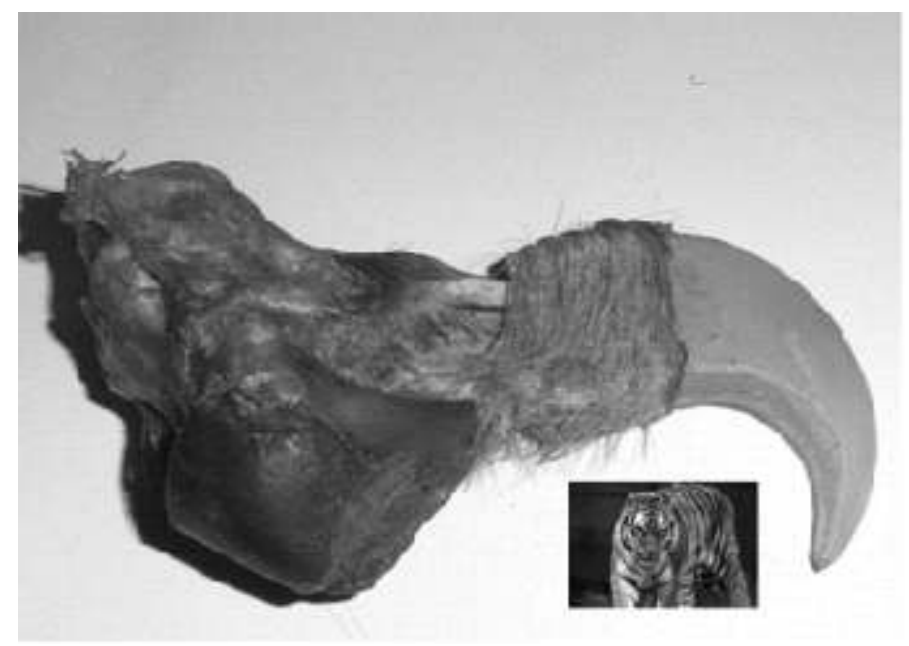

Gambar 3. Kuku Harimau

(Sumber: Dokumentasi Ferry Fernando, 2013) 
Campo, berfungsi sebagai jaguar atau jager, yaitu pasukan tempur/Stoot Tropen. Barisan penyelamat, bernama Kucieng Siam, berfungsi sebagai savior, anti huru-hara. (MID.Jamal,1984:75).

Rombongan Ini merupakan suatu angkatan yang dipimpin oleh masing-masing panglima yang memiliki ilmu silat dan kepandaian tempur yang dapat diandalkan kerajaan.Salah satunya yaitu silat harimau yang dipakai oleh Harimau Campo. Dalam silat harimau perpanjangan tangan penganti kuku harimau diciptakanlah senjata bernama Kurambik. Bentuk kurambik di ilhami dari bentuk kuku harimau atau taring harimau yang melekuk.

Makanya dinamakan kurambik yang sifatnya mengait. Dengan demikian terciptanya senjata kurambik berawal dari terciptanya silat harimau. Dimana seseorang yang memiliki ilmu silat harimau berarti dia juga bisa menggunakan senjata kurambik yang mana kegunaan senjata kurambik pada waktu itu adalah untuk memburu/penyerbu secara diam-diam. (Edwel Yusri Datuk Rajo Gampo Alam).

\section{Filosofi Senjata Kurambik}

a) Sepasang kerambit bila dimainkan, menggambarkan seekor kerbau yang menjadi lambang suku bangsa Minangkabau. Hal ini mengisyaratkan jati diri seorang satria atau pendekar Minangkabau yang sebenarnya.

b) Sepasang kerambit bila disatukan, menggambarkan perlambang hati. Dan barang siapa yang setia kepada hati sanubarinya atau dapat merasakan sumber dari rasa yang selalu menghadap kepada Tuhan, niscaya ia akan selamat lahir bathinnya dan sampai kepada tujuannya. Artinya mengandung nilai ketaqwaan. Namun, jika ingkar atau menyimpang dari hati sanubarinya, maka ia akan celaka karena perbuatannya itu. Hal ini digambarkan dari senjata kerambit yang tajam sisi luar maupun sisi dalamnya, dari luar mampu melindungi ancaman dan dari dalam juga dapat memberi kontrol diri karena jika menyimpang akan menjadi senjata makan tuan. Dengan demikian

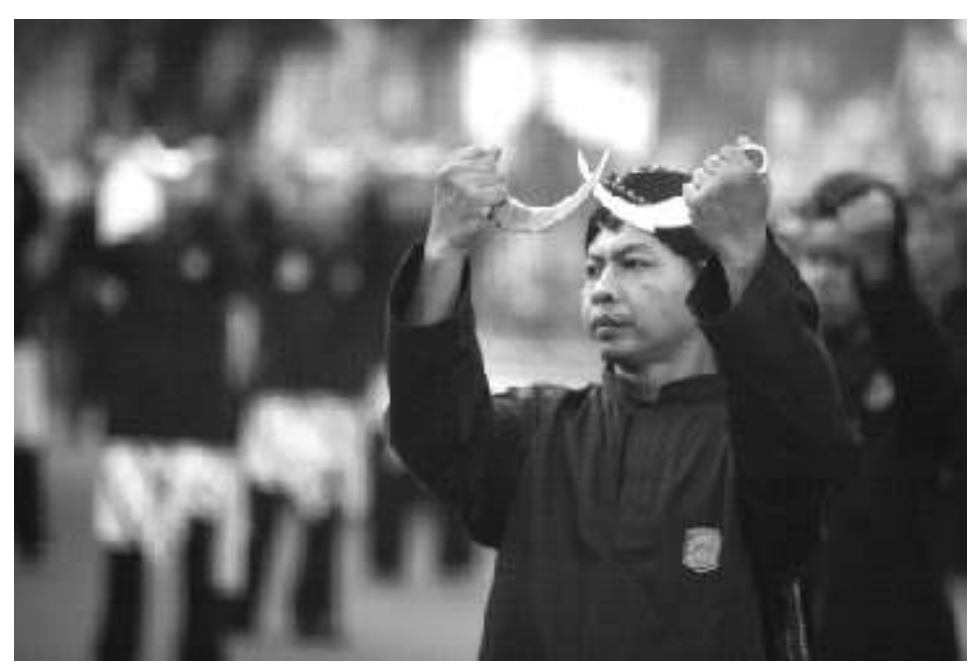

Gambar 4. Permainan Kerambit/kurambik

(Sumber: Dokumentasi Ferry Fernando, 2013) 
untuk meraih kemenangan atau tujuan, maka dalam memainkan senjata kerambit juga harus berpedoman pada hukumnya yakni menjalankan "langkah" dalam "jurus" yang benar, tidak asal melangkah dalam memainkan suatu jurus. Sebab langkah dalam jurus merupakan sebuah hukum dalam pencak silat. Jika menyimpang atau melanggar dari hukum itu, maka akan memperoleh akibat hukumnya atau tergelincir karenanya. Dalam pencak silat, ini apa yang dimaksud sebagai rohnya pencak silat itu sendiri.

c) Dalam memainkan langkah kerambit, kerambit muncul dari sisi atau samping perut, tersembunyi disamping iga atau rusuk. Hal ini mengandung maksud:

a. Kerambit/kurambik ibarat tulang iga (bentuknya melengkung), mengingatkan kepada riwayat seorang wanita, sehingga wajib hukumnya untuk menempatkan wanita pada kedudukan yang terhormat mengingat kedudukannya sebagai seorang ibu. Dalam sistem adat Minangkabau, wanita memperoleh kedudukan yang sangat tinggi (matrilineal).

b. Kerambit/kurambik ibarat tulang rusuk, memperlihatkan bahwa organ-organ tubuh bagian dalam manusia terlindungi oleh rusuk yang dapat membentuk tubuh manusia memiliki alat pertahanan yang kokoh dan kuat. Jika tidak ada tulang rusuk, maka badan menjadi lemah.

Rusuk berfungsi melindungi ancaman dari luar dan ancaman dari dalam agar organ bagian dalam tidak mudah keluar dari badan. Dibalik rusuk juga bersemayam hati atau sumber rasa.
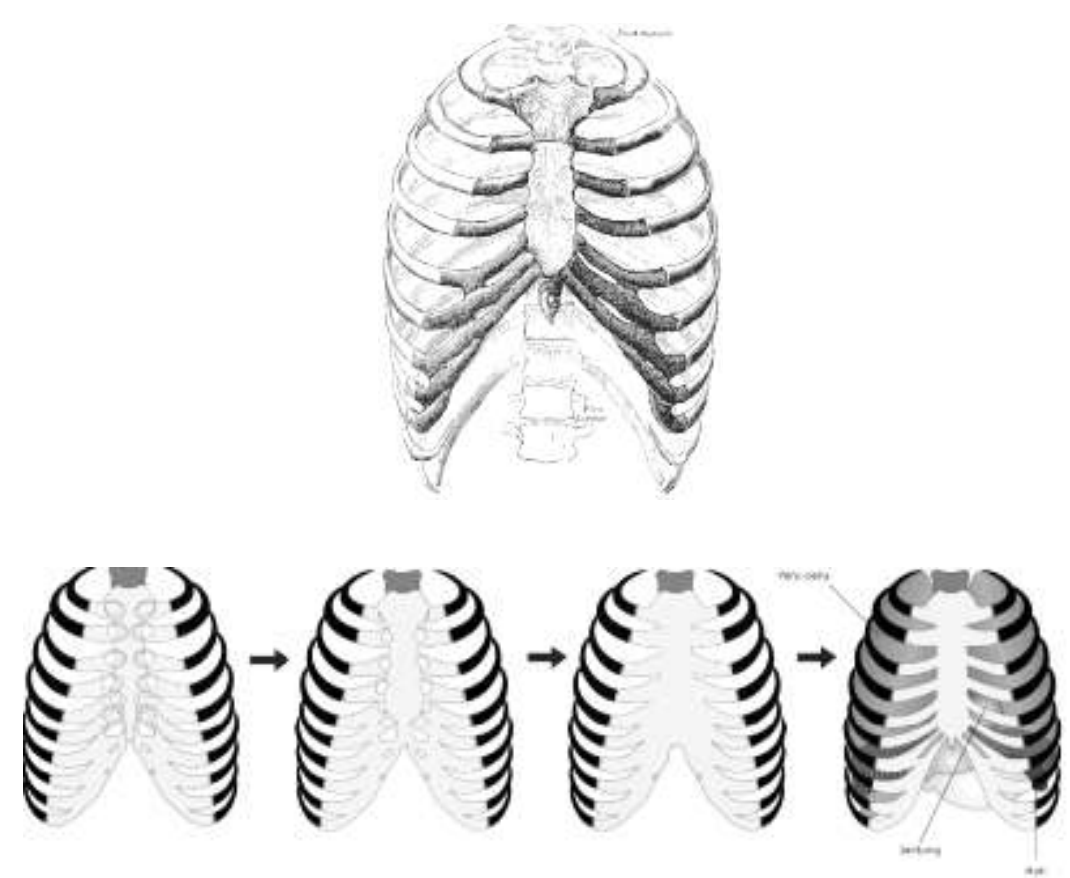

Gambar 5. Tulang Rusuk Manusia

(Sumber: Dokumentasi Ferry Fernando, 2013) 


\section{Jenis - Jenis Kurambik}

Di dalam perkembangannya kurambik/kerambit sangatlah banyak bentuk dan jenisnya. Tetapi asal muasal bentuk kurambik/kerambit ini tidak lepas dari bentuk kuku harimau.

Masyarakat Minangkabau sendiri dalam membuat sebuah produk kebudayaan tidak lepas dari alam sekitarnya baik itu tumbuhan maupun hewan. Ciri-ciri dari kerambit/kurambik ini adalah Bagian luar dan dalam tajam, melengkung setengah lingkaran seperti kuku harimau dengan ujung runcing tajam. Senjata ini sulit dilumpuhkan, kecuali harus menebas sampai putus kedua belah tangan. Penggunaannyapun digenggam dan cukup disembunyikan dibalik tangan. Ada beberapa bentuk dan jenis kurambik/kerambit seperti gambar dibawah ini:
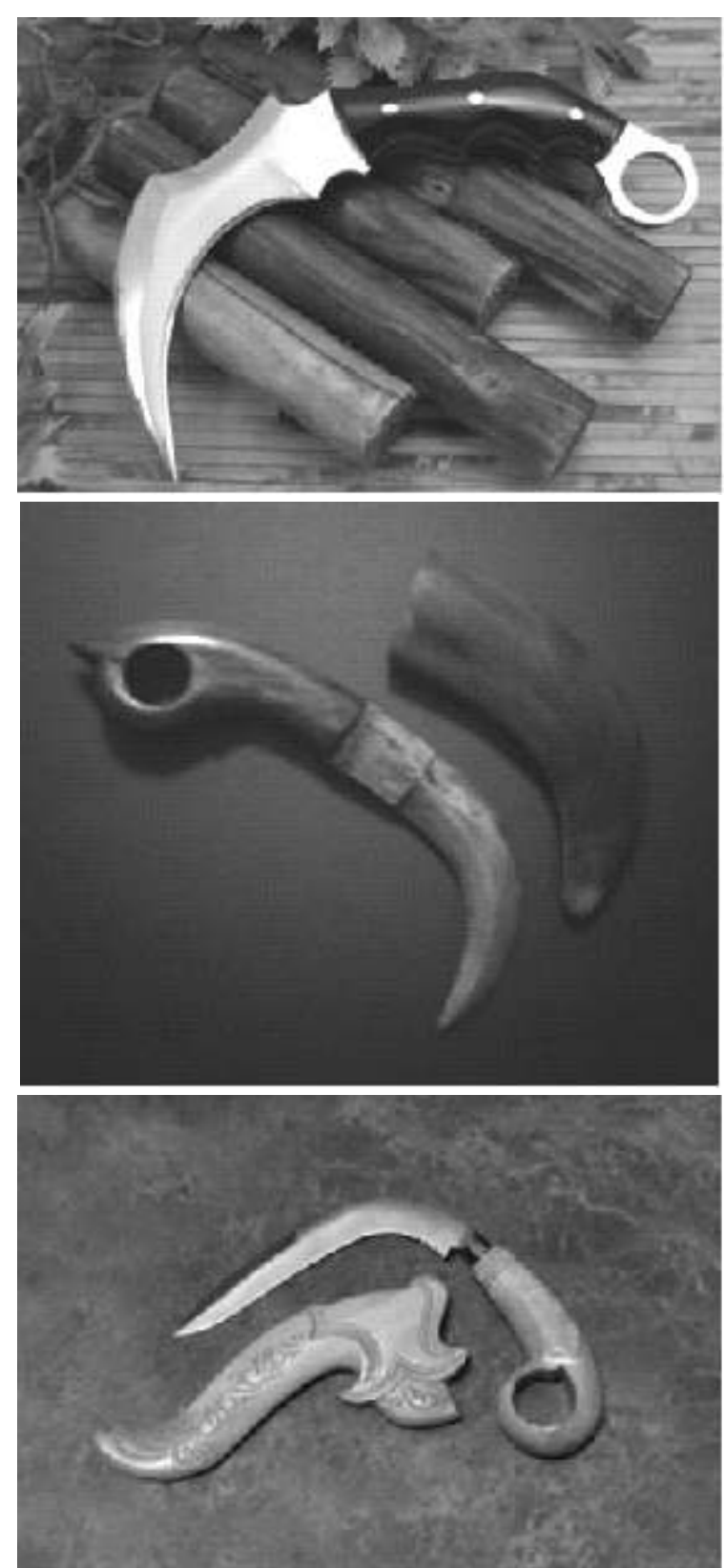

Gambar 6. Bentuk dan jenis Kurambik (Sumber: Dokumentasi Ferry Fernando, 2013) 
Dari gambar diatas jenis kurambik/kerambit yang terdapat di Indonesia ada dua macam yaitu :

1. Kurambik/kerambit Minangkabau :

- Kurambik Kuku Harimau

- Kurambik Lawi Ayam

2. Kurambik/kerambit Jawa Barat :

- Kurambik/kerambik kuku bima

- Kurambik/kerambit kuku hanoman

\section{Cara Memainkan Kurambik}

a. Menjadi sempurna jika dimainkan sepasang dengan 2 tangan posisi atas dan bawah secara bergantian kiri dan kanan. Maksudnya untuk menutup semua celah yang memungkinkan untuk bisa ditembus lawan. Sehingga dengan memainkan sepasang kerambit menjadi sebuah pertahanan yang sangat rapat dan kokoh yang sulit untuk ditembus atau dimasuki oleh serangan lawan yang bagaimanapun hebatnya.

b. Dimainkan khusus untuk pertarungan jarak dekat atau rapat.

c. Setelah ujung kerambit berhasil menembus tubuh lawan, dengan seketika harus dibalikkan atau diputar arah. Hasilnya akan tampak diluar seperti luka dengan robek kecil tetapi di bagian dalam organ-organ tubuh putus. Apabila menyangkut ditangan lawan, akibatnya akan sangat mengerikan yakni semua urat tangan putus terkelupas bahkan tangan bisa potong.
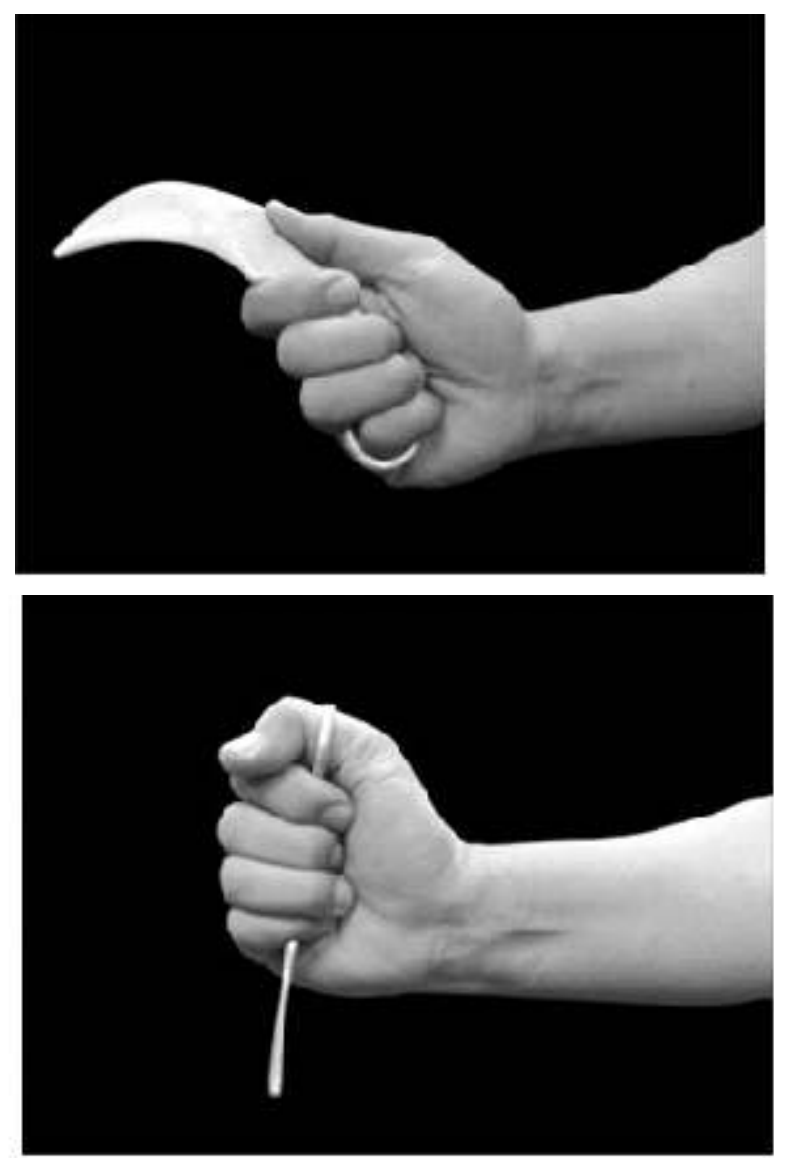

Gambar 7. Cara menggenggam Kurambik (Sumber: Dokumentasi Ferry Fernando, 2013) 


\section{Pembuatan Kurambik}

Pembuatan senjata kurambik ini biasa kita jumpai di daerah Sungai Pua Kab.Agam Sumatera Barat.Dahulunya merupakan tempat pembuatan peralatan-peralatan seni mulai dari gong, talempong, alat-alat rumah tangga yang berbahan logam kuningan dan juga peralatan pertanian mulai dari cangkul, golok, sabit, pisau dan kurambik.

Pembuatan senjata kurambik ini bisa juga kita jumpai di daerah lain di luar Minangkabau seperti Sukabumi, Tasikmalaya, Ciwidey, Tanggerang dan tempat pengrajin senjata lainnya seperti keris, golok, kujang, samurai dan lain sebagainya. Dahulunya pembuatan senjata kurambik ini mempergunakan 7 campuran logam yang gunanya untuk menghadapi seorang musuh yang memiliki ilmu kekebalan pada tubuhnya. Untuk sekarang ini cara seperti itu tidak pernah dijumpai lagi karena memakan waktu yang sangat lama. Kebanyakan pembuatan kurambik itu sendiri lebih praktis dan persis dengan pembuatan senjata-senjata tradisonal lainnya dengan menggunakan bahan baja putih, baja per, cakram motor, klahar truk dan lain-lain.

Pembuatan kurambik ini dilakukan disebuah bengkel atau tempat khusus pengrajin senjata. Tidak hanya kurambik saja melainkan beberapa senjata khas Indonesia bisa di pesan seperti terlihat dibawah ini :

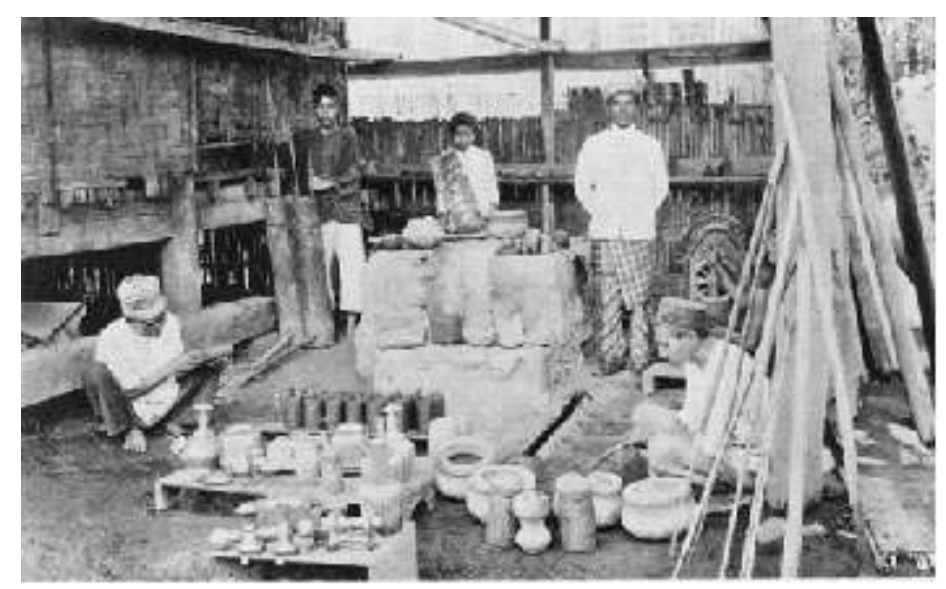

Gambar 8. Pengrajin Di Daerah Sungai Pua Kab.Agam Sumbar (Sumber: http://www.nagari-sungaipua.com/?page=industri)
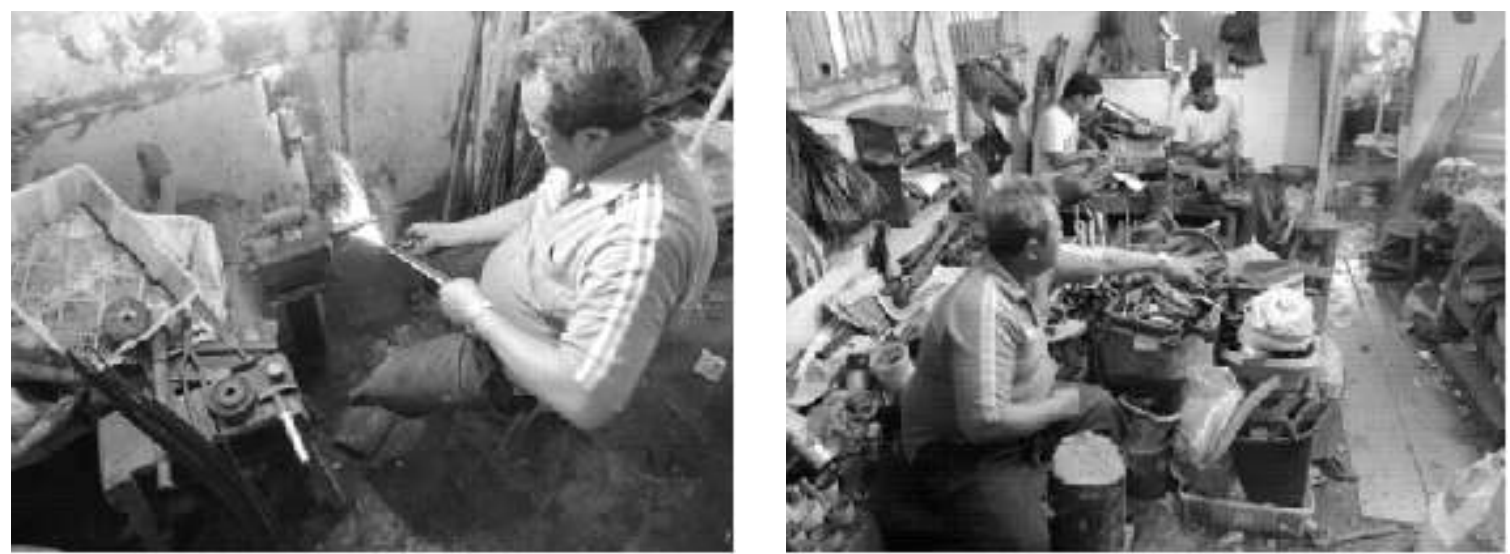

Gambar 9. Suasana Pengrajin Senjata (Sumber: Dokumentasi Ferry Fernando, 2013) 


\section{Para Pedagang Senjata Kurambik}

Di Sumatera Barat penjual senjata tradisional khususnya kurambik bisa ditemukan di daerah kota Bukittinggi. Terletak di kawasan pasar atas blok c, disana berderetan para pedagang senjata dan juga pedagang batu akik yang sudah turun temurun menjual senjata tradisional maupun senjata tajam khas nusantara.

Tidak hanya senjata tetapi disana menjual juga alat-alat pertanian, alat musik, seperti talempong, gong, canang dan alat-alat dapur seperti cetakan kue yang terbuat dari tembaga.Sebut saja Gusti Rama. Dia salah seorang pedagang senjata di kawasan blok C Bukittinggi.
Pemuda ini berasal dari daerah Sungai Pua Kab. Agam Sumatera Barat. Dimana dahulunya kakek dan ayahnya merupakan seorang pengrajin besi dan kuningan di Sungai Pua. Usaha ini turun temurun digeluti sampai sekarang ini dan hasilnya dia merupakan salah satu grosir senjata, alat musik, dan alat-alat keperluan rumah tangga.

Di Bukittinggi pedagang senjata kurambik ini bisa kita temui di daerah luar Sumatera Barat seperti Sukabumi, Garut, Tasimalaya, Yogyakarta, Semarang dan lain sebagainya.Tetapi yang jelas senjata kurambik/kerambit merupakan senjata bela diri khas Minangkabau Sumatera Barat

\section{Para Pengguna Senjata Kurambik}

a. Perguruan Silat Harimau Minangkabau

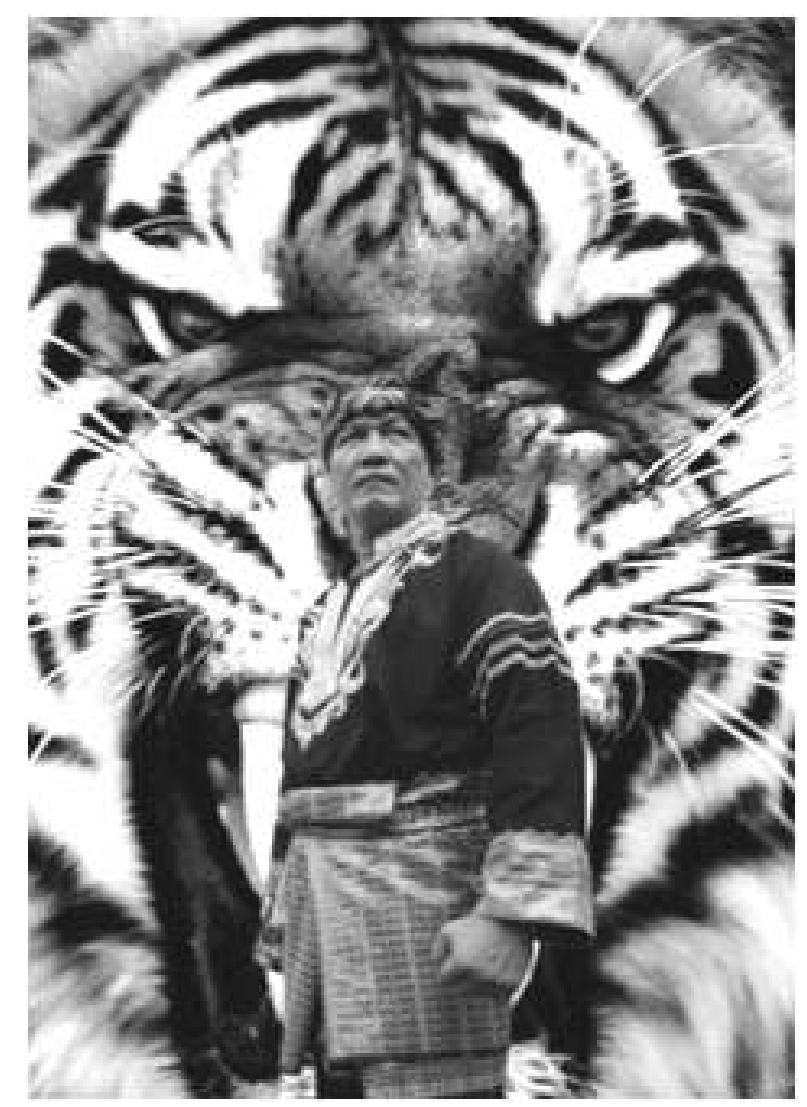

Gambar 10. Guru Besar Silat Harimau Minangkabau Edwel Yusri Datuk Rajo Gampo Alam (sumber :silek-harimau-minangkabau.blogspot.com) 
b. Persaudaraan Setia Hati Terate (PSHT) \& Setia Hati Tunas Muda Winongo
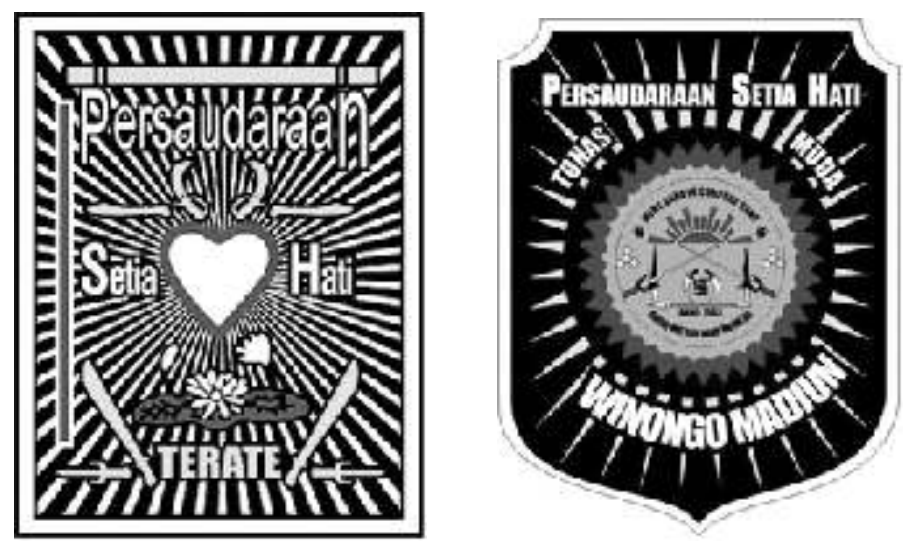

Gambar 11. Lambang PSHT\& Tunas Muda Winongo (sumber :kuat22.wordpress.com/sejarah-psht)

\section{Kesimpulan}

Senjata tradisional merupakan produk suatu kebudayaan yang patut dilestarikan dan dijaga keberadaanya. Indonesia merupakan Negara yang kaya dengan karya seni tradisional, dimana akhir-akhir ini banyak karya seni dan produk budaya Indonesia yang di klaim oleh Negara lain. Kurambik/kerambit adalah senjata beladiri khas Minangkabau Sumatera Barat. Senjata ini banyak tersebar di seluruh Indonesia dan sampai keluar negeri. Tidak banyak yang mengetahui keberadaan senjata ini, terlebih masyarakat Minangkabau sendiri.

Tidak semua perguruan silat di Indonesia memakai senjata ini karena senjata ini hanya diturunkan ilmunya dari para datuk atau raja. Sebut saja perguruan silat harimau Minangkabau, PSH Tunas MudaWinongo, PSHT dan silek kurambik. Dari sekian banyak senjata tradisional di Indonesia belum ada penelitian yang mengangkat secara khusus mengenai keberadaan senjata kurambik/kerambit. Perancangan buku senjata kurambik khas Minangkabau ini dengan memakai teori etnofotografi merupakan salah satu cara untuk melestarikan keberadaan kurambik sebagai salah satu produk budaya bangsa Indonesia. Selain itu diharapkan keberadaan buku senjata kurambik Minangkabau ini yang mampu memberikan informasi mengenai sejarah, filosofi, jenis-jenis, pembuatan dan penggunaan kurambik secara mendetail

Pada proses etnofotografi dibutuhkan waktu yang lama, terkadang waktu yang dibutuhkan selalu berubah di karenakan oleh faktor non teknis seperti cuaca dan keberadaan nara sumber. Kondisi yang susah untuk ditebak terkadang sering dialami, oleh karena itu persiapan yang matang harus diperhatikan untuk meminimalisir hal yang tidak terduga. Wawancara merupakan hal yang sangat penting disaat memulai pemotretan, karena fotografer harus mengetahui garis besar subjek yang harus difoto. Setelah foto selesai sampai tahap evalusi foto, maka tahap selanjutnya mendesain kedalam bentuk buku. Dalam mendesain buku semua fotofoto yang didapat harus disusun dengan sedemikian rupa sehingga menjadi sebuah buku etnofotografi. Penggunaan teks pada judul buku dan juga body copy dari isi harus terlihat jelas dan mudah untuk dibaca. 
Oleh karena itu perancangan buku senjata kurambik khas Minangkabau memberikan suatu pesan moral kepada masyarakat bahwa setiap ucapan atau perkataan yang keluar dari mulut harus bermanfaat, berguna dan berdampak positif terhadap orang lain kemudian untuk diri sendiri dapat menjaga emosi agar tidak keluar kendali. Terbukti dari bentuk ujung senjata yang memiliki double edge. Bentuk senjata yang melengkung diibaratkan seperti tulang rusuk manusia yang mana wanita di dalam riwayatnya berasal dari tulang rusuk pria. Sehingga kita sebagai pria harus menjaga dan melindungi wanita seperti kita menjaga orang tua wanita kita sendiri. Wanita di Minangkabau sangat dihormati karena Minangkabau memiliki garis keturunan ibu (matrilineal) yang hanya ada satu-satunya di dunia. Dalam gerakan silat ketajaman senjata kurambik terlihat dari sentakan disaat memainkannya. Jadi pepatah petitih Minangkabau yang menyebutkan "indak lakang dek paneh, indak lapuak dek hujan" memberikan pengertian kepada masyarakat bahwa senjata kurambik yang ada di dalam hati sanubari orang Minangkabau akan selalu abadi dan tidak akan terkikis oleh perubahan zaman. Sehingga membuat masyarakat Minangkabau sangat disengani di dalam maupun diluar negeri.

\section{DAFTAR PUSTAKA}

Adityawan, Arief \& Tim Litbang Concept. (2010), Tinjauan Desain Grafis, Dari Revolusi Industri hingga Indonesia Kini, PT Concept Media, Jakarta.

Elizabeth E, Graves. (2007). Asal Usul Elite Minangkabau Modern, Jakarta, Yayasan Obor Indonesia

Jamal, Mid. (1986), Filsafat dan Silsilah Minangkabau, CV Tropic, Bukittinggi

Kuswanto, Engkus. (2008). Etnografi Komunikasi, Bandung, Widya Pajajaran.

Karnadi, Hartono (1998), Laporan Penelitian Mimi Sawitri Penjaga Tradisi Tari Topeng Losari Cirebon Kajian Etnofotografis, Yogyakarta, Lembaga Penelitian ISI Yogyakarta.

Karnadi, Hartono (2005), "Proposal Penciptaan Seni, Cita Rasa Makanan Tradisional Yogyakarta dalam desain grafis", PPS ISI Yogyakarta, Yogyakarta

Ningsih, Murni Irian. (2008), Senjata Khas Nusantara. Bandung, CV. Alfarisi Putra.

Rustan, Surianto. (2009), Layout: Dasar dan Penerapannya. Jakarta, Gramedia Pustaka Utama.

Safanayong, Yongky. (2006), Desain Komunikasi Visual Terpadu, Jakarta, Artc Intermedia.

Spradley, James. (2006). Metode Etnografi. Yogyakarta, Tiara Wacana

Susanto, Astrid S. (1979), Komunikasi Dalam Teori dan Praktek, Bandung, Bina cipta. 